\title{
Scientific Contributions in Evolutionary Biology to Study the Roots of Variation in the Existing Life Forms
}

\author{
Nida Tabassum Khan* \\ Department of Biotechnology, University of Balochistan, Pakistan
}

Submission: March 23, 2018; Published: April 12, 2018

*Corresponding author: Nida Tabassum khan, Department of Biotechnology, Faculty of Life Sciences and Informatics, Balochistan University of Information Technology Engineering and Management Sciences (BUITEMS) Quetta, Pakistan, Email: nidatabassumkhan@yahoo.com

Abstract

Evolution is a slow change in the existing organism with the passage of time which results in creating a new species after millions and billion years of its accumulation. This variation in the existing species implies to the change in the genetic material and physical attributes such as structure and is the basis for studying evolutionary relationships between ancestors to descendants. This review discusses the numerous scientific contributions made by eminent scholars and scientists in the field of evolutionary biology to explain variation and its contributing factors which laid the foundation of our present day biology.

Keywords: Lamarckism; Shortia galacifolia; Natural selection; Vestigial; Homo diurnis

\section{Introduction}

\section{Ernst haeckel}

Ernst Haeckel proposed the biogenetic law in 1866 in his manuscript entitled General Morphology of the Organisms [1]. Biogenetic law states that each embryo's developmental stage represents an adult form of an evolutionary ancestor [2] and supported his theory using embryos drawings during different stages of development [3]. In 1874, his work anthropogenie included drawings of embryonic fish, salamanders, tortoises, chicks, pigs, cows, rabbits, and humans at different stages of development placed next to one another for comparison [4].

\section{Asa gray}

Asa Gray known as the "Father of American Botany" was a botanist [5]. He named an unknown herbarium specimen as Shortia galacifolia [6]. He accumulated a more than 200,000 preserved plants, which he donated to Harvard and collected over 1,000 specimens during his visit in American West [7, 8]. His most widely used book was Manual of the Botany commonly known as Gray's Manual [9].

\section{Charles robert darwin}

Charles Robert Darwin was scientist, naturalist, geologist and author [10]. At the age of 22 years old, he was selected as a naturalist for a long journey of scientific on the HMS Beagle. In that voyage, he visited South America, the Galapagos Island, Africa and island in the Pacific Ocean and collected a lots of animals, plants fossils and rocks for his research work [11]. After finishing along five years journey, Darwin returns homeland with a
a. 3000 pages
b. He Collected 1529 species and
c. $\quad 3907$ skins
d. 12 catalogs of plants and animals [12]

He published his first major book on his findings, entitled Zoology of the Beagle [13]. His later research on evolution and natural selection was based on his long journey of Beagle, in which he examined many plants, animals, fossils and the natural earth [14]. Darwin was influenced by the Principle of Geology which was represented by Sir Charles Lyell. He made a new way to observe nature, he explained that small changes can cause a large change. Darwin observed many natural phenomenon such as erosion, earthquake, volcanoes, etc. After his deep observation he noticed that Lyell was correct [15]. The origin of species by natural selection was published in 1859 [16]. He wrote in his book that all organisms are adapted, developed and modified themselves according to their environment for their survival. He said that all the descendent are descended from a common ancestor, there is not different lines of ancestry but as a tree branches and retrenches. It has not happened so he thought that large number of organisms should destroyed before they reproduced. He examined that the species that has the capability to survive in harsh environment by adaptation 
that will be remain. Although the inferior, weak and less adaptive species will be disappear by natural selection [17]. Darwin's theory of evolution by natural selection explained from where the people came and how they developed and evolved from a common ancestor. There is heredity, selection and adaption in species which is due to different factors which affect them in different ways [18]. On that time no one knew about evolution, Darwin's theory of evolution was a great modernization. The idea of Darwin was so difficult for many people to accept on that time. Darwin wrote a few book which was on the basis of his observation of on voyage of Beagle and on his further researches. The books and essays which was written by him supported his theory of evolution.

The names of his famous books were

a. On the origin of species (1859) [19]

b. The voyage of Beagle (1839) [20]

c. The expression of the motions in man and animals (1872) [21]

d. The descent of man and selection in relation to sex (1871) [22]

e. Natural selection [23]

f. Geology observation of South America (1846) [24]

g. The variation of animals and plants under Domestication (1868) [25]

h. The power of movement in plant (1880) [26]

i. Fertilization of orchids (1862) [27]

j. On the movements and habits of Climbing plants (1875) [28]

k. The different forms of flowers on plants of the same species [29]

l. Geology observation of volcanic islands (1844) [30]

\section{Buffon}

George-louis lecher, Comte de Buffon was born in 7 September 1707 at Mont bard, Burgundy at France [31]. He wrote the book Histoire Naturelle and was complete summary of his work [32]. Buffon's concept of species was "Natural progress by unknown gradation and consequently does not submit to our absolute division when passing from one species to another and mostly from one genus to another" [33]. His work has been reviewed largely in its relationship to later thought and work. Accordingly, he was a most often given the dubious honor of being cited as a precursor first of Cuvier then Darwin [34].

\section{Carl-linnaeus}

He is known as the Father of taxonomy and formulated the classification system Systema Naturae [35]. He referred to humanity as Homo diurnis, or "man of the day" in 1735 [36].He was the first to name us Homo sapiens, and to class us primates [37]. Linnaeus classified organisms in to fivecategories; Class, order, genus, species and variety [38]. He divided plant genra according to the number size, placement, shape of stamen and pistils [39]. But he grouped animals on the basis of their teeth, locomotion, type of blood if any, and habitual system like water or land [40]. He estimated about 40,000 plants and animal species, and a few hundred minerals was present on earth [41].

\section{Georges cuvier}

Georges Cuvier whose full name was Jean Léopold Nicolas Frederic. In 1784, he studied comparative anatomy [42]. He wrote an essay on theory which is called "(Correlation of part)" in which he stated that allanatomical body structures were functionally related and dependent on the rest of the body parts of an organism [43]. Furthermore, he explained that any change in an organism's anatomy can cause major change and make them unable to survive [44]. Cuvier purposed that some of the organisms are extinct from the surface of the world or they might be extinct from some part of the globe [45]. At that time, the view of vanishing an organism was unbelievable and not accepted by the people. Therefore, Cuvier studied the fossils found in eighteenth century and passed a theory that some fossils of organisms were found are different from the anatomy of living organisms. For example: the fossils of elephant left in Italy where they could not be found anymore. He discovered that their anatomy were totally disparate from the present elephant's anatomy. Those elephants were gone even from Siberia, Africa, and India. He explained that those organisms which were vanished didn't belong to any organisms present now [46]. Cuvier proposed, by the passage of time earth has gone to sudden changes, and each change has brought new species and vanished the old ones. He claimed that the evidence pointed to an earlier and pre-humen "world" that had been destroyed by some kind of catastrophe. Although he didn't explain why the event must have been sudden, he did imply that it was common and it might be repeated in the future [47]. Cuvier had also contributed to the evolutionary biology through his studies of fossils [48].

He published as many books and essays as he could.

a. Cuvier's 1st research was (Elementary Survey of the Natural History of Animals) in 1797 [49].

b. In 1800-1805, he published (Lessons of Comparative Anatomy) [50].

c. He wrote on (Historical Report on the Progress of the Science) and it was published in 1810 [51].

d. In 1811, he was titled chevalier which means lord [52].

e. In 1812, he did research which was (Research on the Bones of Fossil Vertebrates) [53].

f. In 1825 , his essays and research were published in the form of book which is (Discourse on the Revolutions of the Globe) [54]. 
g. In 1817, Cuvier published his (system of animal classification) [55].

h. In 1815, he wrote an essay on (The Theory of Earth) [56].

\section{Jean- baptiste lamarck}

A French Biologist who proposed Lamarckism, anevolutionary theoryin his book "Philosophic Zoologies", publishedin 1809 [57]. Lamarck also coined the terms biology, Invertebrates and annelida $[58,59]$.

\section{Lamarcks Proposition}

Internal vital force: internal vital force is responsible for the growth of all the living organisms and their components [60].

Effect of surroundings and new essentials: Changing environment affects the living organism resulting in producing species with new structures [61].

Use and disuse of organs: Persistent use of a specific organ will result in its further development whereas organ disuse results in its deterioration [62]

Inheritance of acquired traits: Acquired traits of an organisms is transmitted to the next progeny. After several generations the distinctions produces a novel specie [63].

Lamarck elucidated his theory with the help of examples including evolution of giraffe, webbed toes of aquatic birds, disappearance of limbs in snake, flat fishes, flightless birds and cave dwellers [64].

\section{William bateson}

William Bateson, an English biologist who coined the term genetics to describe the study of heredity [65]. His bookentitled "Materials for the Study of Variation" was published in 1894 [66] .By studying variation and advocating Mendelian genetics, Bateson emphasis on the use of experimental methodology to study genetic inheritance [67].

\section{Malthus thomas robert}

His book entitled Essay on the principle of population was published in 1798 which postulated that for the existence of mankind food is a need and the passion between the sexes will remain nearly in its present state [68].

\section{Conclusion}

Thus the contributions made by these scientific researchers in the field of evolutionary biology is immense to understand variation in the existing life forms.

\section{References}

1. Haeckel E (1866) General morphology of organisms. general outlines of the science of organic forms based on mechanical principles through the theory of descent as reformed by Charles Darwin G. Reimer, Berlin.

2. Gottlieb G (2001) Individual development and evolution: The genesis of novel behavior. In: Gottlieb G (Ed.), Individual development and evolution: The genesis of novel behavior. Psychology Press, UK.

3. Wells J (1999) Haeckel's embryos \& evolution: Setting the record straight. The American Biology Teacher 61(5): 345-349.

4. Haeckel E (1874) Anthropogenie: Keimes-und Stammes-Geschichte des Menschen. In: Haeckel E (Ed.), Anthropogenie: Keimes-und Stammes-Geschichte des Menschen. Leipzig: Engelmann, Germany.

5. Pennell F W (1940) Botanical collectors of the Philadelphia local area. Bartonia (21): 38-57.

6. Jenkins CF (1942) Asa Gray and his quest for Shortia galacifolia Arnoldia. Harvard University, USA 2(3-4): 13-28.

7. Warnement $J$ (1997) Botanical libraries and herbaria in North America. 3. Harvard's botanists and their libraries. Taxon 46(4): 649-660.

8. Chock AK, JF Rock (1963) pp: 1884-1962.

9. Gray A, Robinson BL, Fernald ML (1906) Gray's new manual of botany. In: Gray A, Robinson BL, Fernald ML (Eds.), Gray's new manual of botany. American Book Company, Georgia, USA.

10. Darwin CR (1842) The structure and distribution of coral reefs: being the first part of the geology of the voyage of the beagle, under the command of Capt. Fitzroy, R.N. during the years 1832 to 1836. Smith Elder and Co, London, UK.

11. Darwin C (1933) Diary of the Voyage of HMS Beagle.

12. Barlow N (1946) Charles Darwin and the voyage of the beagle. Philosophical Library, New York, USA.

13. Darwin C (2005) Charles Darwin's zoology notes and specimen lists from HMS Beagle. Cambridge University Press, UK.

14. Darwin C, Wallace AR (1958) Evolution by natural selection.

15. Rudwick MJ (2005) Lyell and Darwin geologists: studies in the earth sciences in the age of reform (818) Variorum.

16. Darwin C, Bynum WF (2009) The origin of species by means of natural selection: or the preservation of favored races in the struggle for life, pp. 441-764.

17. Darwin C (1968) On the origin of species by means of natural selection. Murray Google Scholar.1859 London, UK.

18. Torres A \& Torres FFUA Darwin's Theory of Evolution by Natural Selection.

19. Darwin C (1959) The Origin of Species 1859-1959 Bios 30(2): 67-72.

20. Darwin C (1989) The voyage of the Beagle. 1839. Darwin: The Indelible Stamp.

21. Darwin C (2013) The expression of the emotions in man and animals. Courier Corporation.

22. Darwin C (1888) The descent of man and selection in relation to sex (Vol. 1) Murray.

23. Fisher RA (1999) The genetical theory of natural selection: a complete variorum edition. Oxford University Press,UK

24. Darwin C (1846) Geological observations on South America: Being the third part of the geology of the voyage of the Beagle, under the command of Capt. Fitzroy, RN during the years 1832 to 1836: Smith Elder and Co. London. UK.

25. Darwin C (1868) The variation of animals and plants under domestication 2(1)

26. Darwin C, Darwin F (1881) The power of movement in plants. In: Darwin C, Darwin F (Eds.), The power of movement in plants. D Appleton, New York, USA. 
27. Darwin C (1979) Fertilization of orchids by insects. In: Darwin C (Ed.), Fertilization of orchids by insects. EM Coleman Enterprises, florida, USA.

28. Darwin C (1865) On the movements and habits of climbing plants. Botanical Journal of the Linnean Society 9(33-34): 1-118.

29. Darwin C (1877) The different forms of flowers on plants of the same species. London. John Murray.

30. Darwin C (2011) Geological observations on the volcanic islands, visited during the voyage of HMS Beagle: together with some brief notices on the geology of Australia and the Cape of Good Hope. Cambridge University Press, UK.

31. Leclerc GL (2001) Comte de Buffon. Statisticians of the Centuries 77.

32. Leclerc GL, De Buffon C, Varloot J (1765) Histoire naturelle. Premier discours: De la Manière d'Étudier et de Traiter l'Histoire Naturelle Paris.

33. Sloan PR (1987) From logical universals to historical individuals: Buffon's idea of biological species. Histoire du concept d'espèce dans les sciences de la vie, pp. 101-140.

34. Bowler PJ (1973) Bonnet and Buffon: theories of generation and the problem of species. Journal of the History of Biology 6(2): 259-281.

35. Godfray HC J (2007) Linnaeus in the information age. Nature 446(7133): 259-260.

36. Schiebinger L (1993) Why mammals are called mammals: gender politics in eighteenth-century natural history. The American Historical Review 98(2): 382-411.

37. Notton D, Stringer C, Linnaeus I (2010) Who is the type of Homo sapiens?

38. Cain AJ (1958) Logic and memory in Linnaeus's system of taxonomy In Proceedings of the Linnean Society of London 169(1-2): 144-163.

39. Stace CA (1991) Plant taxonomy and biosystematics. In: Cambridge Stace CA (Ed.), Plant taxonomy and biosystematics. University Press, UK.

40. McKenna M C, Bell SK (1997) Classification of mammals: above the species level. In: McKenna M C, Bell SK (Eds.), Classification of mammals: above the species level. Columbia University Press, USA.

41. Koerner L (1996) Carl Linnaeus in his time and place. Cultures of natural history, pp. 145-162.

42. Rudwick MJ (2008) Georges Cuvier, fossil bones and geological catastrophes: new translations and interpretations of the primary texts. In: Rudwick MJ (Ed.), Georges Cuvier, fossil bones and geologica catastrophes: new translations and interpretations of the primary texts. University of Chicago Press, UK.

43. Baron Cuvier G, Macartney J (1802) Lectures on comparative anatomy. In: Baron Cuvier G, Macartney J (Eds.), Lectures on comparative anatomy. Printed at the Oriental Press, by Wilson and Company for TN Longman and O. Rees, UK.

44. Stocking GW (1964) French anthropology in 1800. Isis 55(2): 134-150.

45. Newell ND (1967) Revolutions in the history of life. Geological Society of America Special Papers 89: 63-92.

46. Brace CL, Agogino GA, Brothwell DR, Clark WL G, Coon C S, et al (1964) The fate of the classic neanderthals: a consideration of hominid catastrophism [and comments and reply]. Current Anthropology 5(1).

47. Stanford PK (1995) For pluralism and against realism about species. Philosophy of Science 62(1): 70-91.

48. Taylor PD (2004) Extinction and the fossil record.
49. Freilich J (2015) Cuvier's history of the natural sciences: twenty-four lessons from antiquity to the renaissance. Theodore Pietsch (edn), Publications Scientifiques du Muséum national d'Histoire naturelle. p. 734.

50. Galaburda AM (1984) The anatomy of language: Lessons from comparative anatomy. Biological perspectives on language 290-302.

51. Outram D (1984) Georges Cuvier: Vocation science and authority in post-revolutionary France. In: Outram D (Ed.), Georges Cuvier: Vocation science and authority in post-revolutionary France. Manchester University Press, England.

52. Soloviev YY (2010) 240th anniversary of the birth of Georges Cuvier (1769-1832). Paleontological Journal 44(6): 708-712.

53. Rudwick M (2000) Georges Cuvier's paper museum of fossil bones. Archives of Natural History 27(1): 51-68.

54. Corsi P (2012) The revolutions of evolution: Geoffroy and Lamarck, 1825-1840. Bulletin du Musée d'Anthropologie préhistorique de Monaco.

55. Appel TA (1987) The Cuvier-Geoffroy debate: French biology in the decades before Darwin. In: Appel TA (Ed.), The Cuvier-Geoffroy debate: French biology in the decades before Darwin. Oxford University Press on Demand, UK.

56. Cuvier G, Jameson R (1827) Essay on the Theory of the Earth. In: Cuvier G, Jameson R (Eds.), Essay on the Theory of the Earth. W. Blackwood, UK.

57. de Monet JBPA (2011) Zoological philosophy: an exposition with regard to the natural history of animals. In: de Monet JBPA (Ed.), Zoological philosophy: an exposition with regard to the natural history of animals. Cambridge University Press, UK.

58. Schiller J (1974) Queries, answers and unsolved problems in eighteenth century biology. History of Science 12(3): 184-199.

59. Hall BK (2012) Evolutionary developmental biology. In: Hall BK (Ed.), Evolutionary developmental biology. Springer Science \& Business Media, Germany.

60. Miquel PA (2007) Bergson and Darwin: From an immanentist to an emergentist approach to evolution. SubStance 36(3): 42-56.

61. Mayr E (1972) Lamarck revisited. Journal of the History of Biology 5(1): 55-94.

62. Nishihara K (2003) Verification of use and disuse theory of Lamarck in vertebrates using biomaterials. Biogenic amines 18(1): 1-18.

63. Landman OE (1991) The inheritance of acquired characteristics. Annual Review of Genetics, 25(1): 1-20.

64. Willey A, Murray J (1911) Convergence in evolution.

65. Lewis EB (1994) Homeosis: the first 100 years. In Genes, Development, and Cancer. In: Lewis EB (Ed.), Homeosis: the first 100 years. In Genes, Development, and Cancer. Springer Netherlands, USA, pp. 505-510.

66. Bateson W (1894) Materials for the Study of Variation.

67. Bateson W (2012) Materials for the study of variation: treated with especial regard to discontinuity in the origin of species. In: Bateson W (Ed.), Materials for the study of variation: treated with especial regard to discontinuity in the origin of species. Cambridge University Press, UK.

68. Malthus TR (1888) An essay on the principle of population: or, A view of its past and present effects on human happiness. In: Malthus TR (Ed.), An essay on the principle of population: or, A view of its past and present effects on human happiness. Reeves \& Turner, Georgia. 
This work is licensed under Creative Commons Attribution 4.0 License

DOI: 10.19080/CTBEB.2018.13.555874
Your next submission with Juniper Publishers will reach you the below assets

- Quality Editorial service

- Swift Peer Review

- Reprints availability

- E-prints Service

- Manuscript Podcast for convenient understanding

- Global attainment for your research

- Manuscript accessibility in different formats ( Pdf, E-pub, Full Text, Audio)

- Unceasing customer service

Track the below URL for one-step submission https://juniperpublishers.com/online-submission.php 